AIM: Behçet's disease (BD) is an inflammatory vasculitis with immunologic, endothelial and neutrophil alterations. Adenosine deaminase (AD) is a marker of T-cell activation and is related to the production of reactive oxygen species by neutrophils with the production of $\mathrm{NO}^{\circ}, \mathrm{O}_{2}^{--}, \mathrm{H}_{2} \mathrm{O}_{2}$ and $\mathrm{OH}^{\circ}$. We reported increased tumour necrosis factor- $\alpha$, soluble interleukin-2 receptor, interleukin- 6 , interleukin-8 and NO in active BD. As there is a relation between cytokines, $T$ cells and oxidative stress in inflammatory diseases, this study further evaluated: (1) plasma AD activity and its correlation with acute phase reactants; (2) thiobarbituric acid-reactive substances (TBARS) as an indicator for lipid peroxidation; and (3) antioxidant enzymes superoxide dismutase (SOD), glutathione peroxidase (GSHPx) and catalase in patients with BD. The effect of disease activity and correlations between the measured parameters were explored.

Metbods: A total of 35 active $(n=17)$ or inactive $(n=$ 18) patients with $B D$ (16 men, 19 women) satisfying International Study Group criteria, and 20 agematched and sex-matched controls (nine men, 11 women) were included in this cross-sectional casecontrol study. AD and TBARS were measured in plasma, catalase in red blood cells (RBC), and SOD and GSHPx in both plasma and RBC in both groups. Acute phase reactants $\left(\alpha_{1}\right.$-antitrypsin, $\alpha_{2}$-macroglobulin, neutrophils, erythrocyte sedimentation rate) were used to classify patients as active or inactive.

Results: Plasma AD (mean \pm standard error of the mean, $36.1+0.7 \mathrm{U} / 1)$ and TBARS $(4.2+0.1 \mathrm{nmol} / \mathrm{ml})$ levels were significantly (for each, $p<0.001$ ) higher in $B D$ than in controls $(24.1+0.8 \mathrm{U} / 1$ and $1.6+0.1$ nmol/ml, respectively). RBC catalase activity was significantly $(p<0.001)$ lower in BD than in controls $(120.9 \pm 3.8$ versus $160.3 \pm 4.1 \mathrm{k} / \mathrm{g}$ haemoglobin $)$. SOD and GSHPx activities were significantly lower in both plasma and erythrocytes of patients with BD than in controls (plasma SOD, $442.4 \pm 8.6$ versus $636.4 \pm 9.2$ $\mathrm{U} / \mathrm{ml}, \quad p<0.001 ;$ RBC SOD, $3719.2+66.0$ versus $4849.7 \pm 49.0 \mathrm{U} / \mathrm{g}$ haemoglobin, $p<0.001$; plasma GSHPx, $73.1+1.5$ versus $90.6+2.9 \mathrm{U} / \mathrm{ml}, p<0.001$; RBC GSHPx, $600.7 \pm 8.0$ versus $670.6 \pm 10.1 \mathrm{U} / \mathrm{g}$ haemoglobin, $p<0.001)$. Active BD patients had significantly lower antioxidant enzymes (except RBC catalase) and higher AD and TBARS levels than inactive subjects (for each, $p<0.01$ ). When considering all BD patients, a significant positive correlation was present between AD and TBARS $(p<0.001)$ whereas both $A D$ and TBARS were negatively correlated with antioxidant enzymes (for each, $p<0.05$ ). Conclusions: AD and lipid peroxidation are increased and associated with defective antioxidants in BD, suggesting interactions between activated $T$ cells and neutrophil hyperfunction. Measures of pro-oxidative stress and antioxidative defence with $\mathrm{AD}$ activity as an indicator of T-cell activation can be considered as significant supportive diagnostic indicators, especially in active disease. In addition, strengthening the antioxidant defence may contribute to treatment modalities.

Key words: Adenosine deaminase, Behçet's disease, Catalase, Free radical, Glutathione peroxidase, Superoxide dismutase, Thiobarbituric acid-reactive substances

\section{Adenosine deaminase enzyme activity is increased and negatively correlates with catalase, superoxide dismutase and glutathione peroxidase in patients with Behçet's disease: original contributions/clinical and laboratory investigations}

Kuddusi Erkiliç ${ }^{1}$, Cem Evereklioglu ${ }^{1, C A}$, Mustafa Çekmen ${ }^{2}$, Abdullah Özkiris ${ }^{1}$, Fuat Duygulu ${ }^{1}$ and Hakki Dogan ${ }^{1}$

${ }^{1}$ Department of Ophthalmology, Erciyes University Medical Faculty, Sivas Cad, Cebeci Apt. A-Blok 175/15, TR-38020 Kayseri, Turkey; ${ }^{2}$ Department of Biochemistry, Kocaeli University Medical Faculty, Kocaeli, Turkey

\author{
${ }^{\mathrm{CA}}$ Corresponding Author \\ Tel: +90352 2358265 \\ Fax: + 903522358365 \\ E-mail: evereklioglu@hotmail.com
}




\section{Introduction}

Adenosine deaminase (AD) is an enzyme that is required for lymphocyte proliferation, maturation and differentiation with detected biologic activity, particularly in $\mathrm{T}$ cells. ${ }^{1} \mathrm{AD}$ activity is known to be increased in inflammatory diseases characterised by T-cell activation and proliferation. Therefore, AD is considered a marker of T-cell activation. ${ }^{2}$ In addition, overproduction of reactive oxygen species (ROS) including hydrogen peroxide $\left(\mathrm{H}_{2} \mathrm{O}_{2}\right)$, superoxide anion $\left(\mathrm{O}_{2}^{-}\right)$, nitric oxide $\left(\mathrm{NO}^{\bullet}\right)$ and singlet oxygen $\left({ }^{1} \mathrm{O}_{2}\right)$ creates a condition known as oxidative stress, resulting in the amplification of the inflammatory response. ${ }^{3}$ Self-propagating lipid peroxidation (LPO) against membrane lipids begins and endothelial dysfunction ensues. Endogenous free radical scavenging enzymes (FRSEs) such as superoxide dismutase (SOD), glutathione peroxidase (GSHPx) and catalase are, however, involved in the disposal of $\mathrm{O}_{2}^{--}$and $\mathrm{H}_{2} \mathrm{O}_{2}$. First, SOD catalyses the dismutation of $\mathrm{O}_{2}^{--}$to $\mathrm{H}_{2} \mathrm{O}_{2}$ and molecular oxygen $\left(\mathrm{O}_{2}\right)$, resulting in selective $\mathrm{O}_{2}^{\cdot-}$ scavenging. Then, GSHPx and catalase independently decompose $\mathrm{H}_{2} \mathrm{O}_{2}$ to $\mathrm{H}_{2} \mathrm{O} .{ }^{4}$ When free radicals are generated in excess or when FRSEs are defective, however, $\mathrm{H}_{2} \mathrm{O}_{2}$ is reduced into hydroxyl radical $\left(\mathrm{OH}^{\bullet}\right)$, which is one of the highly reactive ROS.

Behçet's disease (BD), first described by the Turkish Dermatologist Prof. Dr Hulusi Behçet in $1937^{5}$ as orogenital ulcerations with hypopyon uveitis, is a chronic relapsing inflammatory vasculitis characterised by endothelial dysfunction, neutrophil hyperfunction and ROS overproduction. ${ }^{6}$ It occurs endemically in Turkey, the Middle East and Japan, with a 3:2 male to female ratio, the population derived from the ancient Silk Road. ${ }^{6}$ It begins between the second and fourth decades of life (range, $0-72$ years) and affects every tissue in the body including the cornea, ${ }^{7}$ inner ear, ${ }^{8}$ kidney, ${ }^{9}$ and the lung. ${ }^{10}$ Although several aetiopathogenetic molecules have been implicated, ${ }^{6,11}$ the intermittent nature and the lack of consistent response to therapy make the underlying aetiology difficult to define. Diagnosis is usually based on its clinical presentations and there is, however, no any specific laboratory test to make the diagnosis. It is therefore of great importance to determine the factor(s) that may lead to disease and to find some rapid and useful laboratory test(s) for the diagnosis of this unique disorder.

We demonstrated that adrenomedullin, ${ }^{12}$ leptin, ${ }^{13}$ homocysteine and endothelin- $1^{14}$ might participate in the aetiopathogenesis of $\mathrm{BD}$. In addition, we reported that pro-inflammatory cytokines $^{15}$ tumour necrosis factor (TNF)- $\alpha$, soluble interleukin-2 receptor (sIL-2R), interleukin (IL)-6 (inducers of $\mathrm{NO}^{\bullet}$ synthesis), chemokine IL-8, and $\mathrm{NO}^{\bullet 16}$ (most abundant free oxygen radical in the body) were increased in patients with $\mathrm{BD}$, suggesting a new activity marker for $\mathrm{NO}^{\bullet}$. To test the inter-relationship between T-cell hyperfunction, oxidative stress and ROS overproduction in inflammatory BD, this study further investigated: (1) the activity of AD in plasma as an index of T-lymphocyte hyperfunction; (2) the catalytic activity of endogenous antioxidant FRSEs SOD and GSHPX in both plasma and erythrocytes; (3) the catalytic activity of catalase in erythrocytes; and (4) the levels of thiobarbituric acid-reactive substances (TBARS) in plasma as an indicator for LPO status in patients with BD. We also assessed the effect of disease activity and evaluated the possible correlations between acute phase reactants, AD, LPO and FRSEs.

\section{Materials and methods}

\section{Patients, controls, and disease classification}

Informed consent was obtained from all participants in both groups. Patients with BD were recruited from the Departments of Ophthalmology and Dermatology (Behçet's services) at the university hospital. Thirty-five patients with active or inactive BD (16 men, 19 women) with a mean age of 32.6 years, and 20 age-matched and sex-matched hospital-based healthy volunteers (nine men, 11 women) with a mean age of 31.7 years from a similar ethnic origin were enrolled in this cross-sectional investigation. Patients with BD had to fulfil the International Study Group criteria for the diagnosis of $\mathrm{BD}^{17}$ (Table 1). Exclusion criteria in both groups were hepatic or renal diseases, alcoholics, diabetes, essential hypertension, pregnancy, malignancy or another chronic inflammatory disease and the history of recent medications.

Active $(n=17)$ and inactive $(n=18) \mathrm{BD}$ patients were classified by both laboratory and clinical findings because there was no clinically acceptable scoring system or standard laboratory screening profile to define the severity of $\mathrm{BD}$. In laboratory assessment, neutrophil count, erythrocyte sedimentation rate (ESR), and acute phase reactants $\left(\alpha_{1^{-}}\right.$ antitrypsin and $\alpha_{2}$-macroglobulin levels) were measured and used as the indicators for disease activity. ${ }^{12,15,16}$ Patients' details were obtained from case notes, and ocular examinations were performed by two experienced ophthalmologist using a standard procedure. In clinical evaluation, worsening of clinical symptoms at the time of the present investigation with having at least three of the four major symptoms (oral aphthae, genital ulceration, cutaneous lesions, and anterior and/or posterior uveitis) were considered to be the active period of the disease. The inactive patients had no any symptoms and signs of 
Table 1. Diagnostic criteria and clinical features of patients with active or inactive Behçet's disease (International Study Group criteria for the diagnosis of Behçet's disease* ${ }^{17}$

\begin{tabular}{|c|c|c|c|c|c|c|c|c|c|c|}
\hline $\begin{array}{l}\text { Patient } \\
\text { number }\end{array}$ & $\begin{array}{l}\text { Age (years)/ } \\
\text { gender }\end{array}$ & Course (years) & $\begin{array}{c}\text { Oral } \\
\text { aphthae }\end{array}$ & $\begin{array}{c}\text { Genital } \\
\text { ulcers }\end{array}$ & $\begin{array}{l}\text { Ocular } \\
\text { lesions }\end{array}$ & $\begin{array}{c}\text { Pathergy } \\
\text { test }^{t}\end{array}$ & Thrombophlebitis & $\begin{array}{l}\text { Erythema } \\
\text { nodosum }\end{array}$ & $\begin{array}{l}\text { Acneiform } \\
\text { nodules }\end{array}$ & Pseufofolliculitis \\
\hline $1^{\S}$ & $20 /$ male & 1 & + & - & + & + & - & - & - & + \\
\hline $2^{\S}$ & 40/female & 14 & + & + & + & - & - & + & + & - \\
\hline $3^{\S}$ & $27 /$ male & 3 & + & + & + & + & - & - & - & + \\
\hline $4^{\S}$ & $30 / \mathrm{male}$ & 3 & + & + & + & - & - & - & + & + \\
\hline $5^{\S}$ & $48 /$ female & 7 & + & - & + & + & + & - & + & - \\
\hline $6^{\S}$ & $34 / \mathrm{male}$ & 5 & + & + & - & + & - & + & - & + \\
\hline $7^{\S}$ & $35 / \mathrm{male}$ & 8 & + & + & - & - & + & - & + & - \\
\hline $8^{\S}$ & $37 / \mathrm{male}$ & 12 & + & + & + & - & - & - & + & - \\
\hline $9^{\S}$ & 35/female & 13 & + & + & - & + & - & - & + & + \\
\hline $10^{\S}$ & $25 / \mathrm{male}$ & 6 & + & + & + & - & - & - & - & - \\
\hline $11^{\S}$ & $43 /$ female & 24 & + & + & - & + & + & - & + & + \\
\hline $12^{\S}$ & $50 /$ female & 29 & + & + & + & + & - & + & - & - \\
\hline $13^{\S}$ & $30 /$ female & 3 & + & + & + & - & - & - & - & + \\
\hline $14^{\S}$ & $18 /$ female & 1 & + & + & - & _- & - & + & - & + \\
\hline $15^{\S}$ & $33 / \mathrm{male}$ & 8 & + & - & - & + & - & + & + & - \\
\hline $16^{\S}$ & $29 /$ female & 5 & + & - & + & + & - & - & - & + \\
\hline $17^{\S}$ & 30/female & 4 & + & + & + & - & + & - & + & - \\
\hline 18 & 50/female & 27 & + & + & + & - & - & + & + & - \\
\hline 19 & $28 / \mathrm{male}$ & 6 & + & + & - & + & - & - & + & - \\
\hline 20 & $31 /$ female & 4 & + & + & - & + & - & - & + & + \\
\hline 21 & $31 / \mathrm{male}$ & 11 & + & + & - & - & - & - & + & + \\
\hline 22 & $32 /$ female & 4 & + & + & - & - & + & - & + & - \\
\hline 23 & $33 /$ female & 6 & + & + & + & + & - & - & - & - \\
\hline 24 & $32 / \mathrm{male}$ & 13 & + & + & - & + & + & - & + & + \\
\hline 25 & 20/female & 4 & + & + & + & - & - & - & + & - \\
\hline 26 & $42 /$ female & 17 & + & + & + & + & - & - & - & + \\
\hline 27 & $25 /$ female & 4 & + & + & + & - & + & - & - & + \\
\hline 28 & $32 /$ female & 9 & + & + & + & + & - & - & + & - \\
\hline 29 & $33 / \mathrm{male}$ & 7 & + & - & - & + & - & + & + & + \\
\hline 30 & $52 /$ female & 21 & + & + & + & - & - & - & + & - \\
\hline 31 & $35 /$ male & 5 & + & + & - & + & - & - & + & + \\
\hline 32 & $38 / \mathrm{male}$ & 11 & + & + & + & + & + & - & - & + \\
\hline 33 & 19/female & 3 & + & + & - & - & - & - & + & + \\
\hline 34 & $22 /$ male & 2 & + & + & - & - & - & - & + & + \\
\hline 35 & $25 / \mathrm{male}$ & 2 & + & + & + & + & - & - & - & + \\
\hline
\end{tabular}

을 $\quad$ *Oral aphthae plus two of the following criteria: genital ulcers, ocular lesions, cutaneous lesions, pathergy test positivity

$\vec{N} \quad$ tUnilateral or bilateral (anterior and/or posterior) uveitis.

*Observation of a pustular lesion by physician at $24-48 \mathrm{~h}$.

¿̊. sActive patients with Behçet's disease. 
disease activity at least 4 weeks before admission. The diagnosis of uveitis was made according to the International Uveitis Study Group. ${ }^{18}$

\section{Sample collection}

This was a double-blind study. Therefore, both laboratory personnel and physicians taking the blood were blinded to the group of the subject. In both groups, whole-blood samples were taken by venipuncture from an antecubital peripheral vein using a 25-gauge needle, avoiding haemolysis, into evacuated Vacutainer plain tubes with ethylenediamine tetraacetic acid during the resting position in the morning hours (8:00-10:00 h) after an overnight fast and $30 \mathrm{~min}$ of supine rest. The same procedures were applied to all BD patients and control subjects. Standard blood screening parameters (red blood cell (RBC) count, platelet count, sodium, potassium, blood urea nitrogen (BUN), creatinine, aspartate, and alanine aminotransferase) and routine urine analyses had to be within normal limits. These parameters were tested by a routine autoanalyser (Coulter-STKS; Coulter Electronics, Luton, UK).

None of the patients with BD and the control volunteers received any systemic or topical medication on admission at least 1 month prior to blood collection. The samples were centrifuged at $3000 \times g$ for $10 \mathrm{~min}$ at $4{ }^{\circ} \mathrm{C}$, and the harvested plasma was collected, subdivided and transferred into polyethylene tubes. Subdivided samples were immediately frozen at $-70^{\circ} \mathrm{C}$ to be used in the assay of plasma SOD and GSHPx, AD and TBARS. The buffy coat on the erythrocyte sediment was carefully separated. The erythrocytes were subsequently washed twice with two volumes of $0.9 \%$ sodium chloride solution to remove the plasma remnants. Following this, the erythrocytes were haemolysed with two-fold volumes of ice-cold distilled water. After centrifugation $\left(5000 \times g, 10 \mathrm{~min}, 4^{\circ} \mathrm{C}\right)$ the supernatant was subdivided and transferred into polyethylene tubes and frozen at $-70^{\circ} \mathrm{C}$ to be used in the assay of RBC SOD, GSHPX and catalase activities. The haemoglobin (Hb) content was also measured, and enzyme activity was determined per milligram of $\mathrm{Hb}$.

\section{Neutrophil count, ESR, $\alpha_{1}$-antitrypsin and $\alpha_{2}$ - macroglobulin assay for disease activity}

Neutrophil counting was performed by the same automated blood counter as earlier. $\alpha_{1}$-Antitrypsin and $\alpha_{2}$-macroglobulin levels were measured by the Behring nephelometer 100 analyser (Dade Behring, Messer Griesheim, Frankfurt, Germany). The ESR was determined by the classical Westergren method.

\section{Erythrocyte catalase assay}

The activity of catalase in subdivided supernatant was measured according to the method of $\mathrm{Aebi}^{19}$ by monitoring the initial rate of disappearance of $\mathrm{H}_{2} \mathrm{O}_{2}$ (initial concentration, $10 \mathrm{mM})$ at $240 \mathrm{~nm}(e=0.041$ $\mathrm{mmol}^{-1} \times 1 \times \mathrm{cm}^{-1}$ ) in a cuvette containing 10.5 $\mathrm{mM} \mathrm{H}_{2} \mathrm{O}_{2}$ in $1 \mathrm{ml}$ of $50 \mathrm{mM}$ phosphate buffer $(\mathrm{pH} 7$, $25^{\circ} \mathrm{C}$ ), in a spectrophotometer. The result was reported as a constant rate per second per gram of $\mathrm{Hb}(k / \mathrm{g} \mathrm{Hb})$.

\section{Erythrocyte and plasma SOD assay}

The activity of SOD in subdivided supernatant and plasma was measured according to the method of Sun et $a l .^{20,21}$ by determining the inhibition of nitroblue tetrazolium reduction, with xanthinexanthine oxidase used as an $\mathrm{O}_{2}^{--}$generator. Activity was assessed in the ethanol phase of the lysate after $1.0 \mathrm{ml}$ of ethanol/chloroform mixture $(5 / 3, \mathrm{v} / \mathrm{v})$ was added to the same volume of the haemolysate and centrifuged. One unit of SOD is defined as the amount of SOD that inhibits the rate of nitroblue tetrazolium reduction by $50 \%$. Results were defined as units per millilitre of plasma or units per gram of $\mathrm{Hb}(\mathrm{U} / \mathrm{ml}$ plasma or $\mathrm{U} / \mathrm{g} \mathrm{Hb})$.

\section{Erythrocyte and plasma GSHPx assay}

The activity of GSHPx in subdivided supernatant and plasma was measured according to the method of Paglia and Valentine. ${ }^{22}$ Enzyme activity was determined from the oxidation of reduced NADPH in the presence of $\mathrm{H}_{2} \mathrm{O}_{2}$ used as substrate. The decrease in concentration of NADPH was monitored and recorded at $340 \mathrm{~nm}$ in a mixture containing reducted

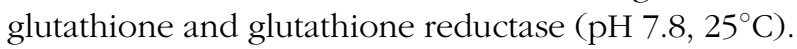
Enzyme units were defined as the number of micromoles of NADPH oxidised per minute. Results were defined as international units per millilitre of plasma or units per gram of $\mathrm{Hb}(\mathrm{U} / \mathrm{ml}$ plasma or $\mathrm{U} / \mathrm{g} \mathrm{Hb})$.

\section{Plasma TBARS assay for LPO}

LPO is frequently investigated in biomedical research, and the assays for TBARS are much more widely used than any other index of LPO in biological samples. ${ }^{23}$ Thiobarbituric acid reacts with LPO aldehydes, such as malondialdehyde (MDA). Therefore, assessment of TBARS is a useful indice of oxidative deterioration and LPO determination in body fluids. ${ }^{2}$ The level of plasma TBARS was estimated according to the method described by Wasowicz et al. ${ }^{24}$ The principal of the method is based on the coupling of TBARS with thiobarbituric acid. All measurements (standards and samples) were done at the upper $n$-butanol phase of the reaction mixture. In brief, $50 \mathrm{ml}$ of 
plasma or an adequate volume of MDA working standard solution was introduced into $10 \mathrm{ml}$ glass tubes containing $1 \mathrm{ml}$ of distilled water. After addition of $1 \mathrm{ml}$ of the solution containing $29 \mathrm{mmol} / \mathrm{l}$ of TBARS in acetic acid and mixing, the samples were placed in a water bath and heated for $1 \mathrm{~h}$ at 95$100^{\circ} \mathrm{C}$. After the samples were cooled, $25 \mu \mathrm{l}$ of $5 \mathrm{~mol} / 1$ HCI was added, and the reaction mixture was extracted by agitation for $5 \mathrm{~min}$ with $3.5 \mathrm{ml}$ of $n$ butanol. The butanol phase was separated by centrifugation at $1500 \times g$ for $10 \mathrm{~min}$. The butanol extract was measured with a spectrofluorometer (F-4010 fluorescence spectrophotometer; Hitachi, Tokyo, Japan) at wavelengths of $525 \mathrm{~nm}$ for excitation. The calibration curve was prepared with MDA standards of $0-10 \mu \mathrm{mol} / \mathrm{l}$. Intra-assay and inter-assay CVs were $3.5 \%$ and $6 \%$, respectively. Results were expressed as nanomoles per millilitre.

\section{Plasma AD assay}

The activity of AD in plasma was measured according to the method of Giusti. ${ }^{25}$ Optical density was measured spectrophotometrically at $265 \mathrm{~nm}$ in an assay mixture (final volume, $2 \mathrm{ml}$ ) containing 0.025 $\mathrm{nM}$ adenosine, $10 \mathrm{nM}$ Tris- $\mathrm{HCl}(\mathrm{pH} 7.4), 0.15 \mathrm{M}$ sodium chloride, $1.25 \%$ glycerol, and $0.02 \mathrm{ml}$ of serum. One unit of activity represents the deamination of $1 \mu \mathrm{M}$ adenosine $/ \mathrm{min}$ at $37^{\circ} \mathrm{C}$ temperature and is expressed as units per litre (U/1).

\section{Calculations and statistics}

Kruskal-Wallis variance analysis or the Mann-Whitney U-test was used as indicated for statistical pairwise comparison of groups, and results were expressed as mean \pm standard error. Spearman's correlation coefficients $(r)$ were performed to determine whether there is any correlation between antioxidant enzymes and LPO or AD activity. Two-tailed significance values were used and $p<0.05$ was considered significant. Statistical analysis was performed with
Statistical Package for the Social Sciences for Windows (Release 7.5; SPSS/PC+ Inc., Chicago, IL, USA).

\section{Results}

Oral aphthae was present in all BD patients (100\%) (Table 1$)$. Twenty patients $(58.8 \%)$ had a variety of ocular inflammation (anterior iridocyclitis or hypopyon uveitis, posterior retinal vasculitis or vitreal cells, or panuveitis), and 32 of 34 patients (94.1\%) had various cutaneous lesions (acneiform nodules, thrombophlebitis, erythema nodosum, pseudofolliculitis). Genital ulcerations were described in 30 patients (88.2\%), and the pathergy test (observation a pustular lesion after needlestick by a physician at 24-48 h) was positive in 19 patients (55.9\%). Additional findings were articular symptoms and signs (arthralgia, arthritis, sacroiliitis) in 18 patients (82.3\%), neurological symptoms (migraine-like headache) in seven patients (20.5\%), and gastrointestinal system symptoms and signs (appendicitis like pain, melena) in five patients (14.7\%).

The age and sex ratio was similar $(p>0.05)$ between groups. Active BD patients had significantly higher levels for acute-phase reactants than patients in the inactive stage $(p<0.001)$ or control subjects $(p<0.001)$ (Table 2). Mean RBC catalase activity was significantly $(p<0.001)$ lower in BD patients $(120.9 \pm 3.8 \mathrm{k} / \mathrm{g} \mathrm{Hb})$ than controls $(160.3 \pm 4.1 \mathrm{k} / \mathrm{g}$ $\mathrm{Hb}$ ). Mean plasma and RBC activities of SOD and GSHPx were significantly lower in patients with BD than in control subjects (plasma SOD, 442.4 \pm 8.6 versus $636.4 \pm 9.2 \mathrm{U} / \mathrm{ml}, \quad p<0.001 ; \quad \mathrm{RBC} \mathrm{SOD}$, $3719.2 \pm 66.0$ versus $4849.7 \pm 49.0 \mathrm{U} / \mathrm{g} \mathrm{Hb}, p<$ 0.001 ; plasma GSHPx, $73.1 \pm 1.5$ versus $90.6 \pm 2.9$ $\mathrm{U} / \mathrm{ml}, \quad p<0.001$; RBC GSHPx, $600.7 \pm 8.0$ versus $670.6 \pm 10.1 \mathrm{U} / \mathrm{g} \mathrm{Hb}, p<0.001)$. Mean plasma AD activity was significantly $(p<0.001)$ higher in patients than control volunteers $(36.1 \pm 0.7$ versus $24.1 \pm 0.8 \mathrm{U} / 1)$. Plasma TBARS levels in patients and control subjects were $4.2 \pm 0.1$ and $1.6 \pm 0.1 \mu \mathrm{mol} / 1$,

Table 2. Comparative analysis of acute phase reactants $\alpha_{1}$-antitrypsin and $\alpha_{2}$-macroglobulin, erythrocyte sedimentation rate and polymorphonuclear leukocyte count in patients with active or inactive Behçet's disease and healthy control volunteers: statistical analysis

\begin{tabular}{lccc}
\hline & $\begin{array}{c}\text { Active patients }(n=17) \\
\text { (8 men, } 9 \text { women) }\end{array}$ & $\begin{array}{c}\text { Inactive patients }(n=18) \\
\text { (8 men, 10 women) }\end{array}$ & $\begin{array}{c}\text { Control subjects }(n=20) \\
\text { (9 men, 11 women) }\end{array}$ \\
\hline Age* (years) & $33.1 \pm 2.1$ & $32.2 \pm 2.1$ & $31.7 \pm 1.8$ \\
$\alpha_{1}$-Antitrypsin (mg/dl) & $223.5 \pm 6.7^{\dagger}$ & $154.5 \pm 4.8$ & $125.0 \pm 7.8$ \\
$\alpha_{2}$-Macroglobulin (mg/dl) & $274.5 \pm 7.8^{\dagger}$ & $198.0 \pm 7.3$ & $144.1 \pm 5.6$ \\
ESR (mm/h) & $43.1 \pm 2.0^{\dagger}$ & $21.2 \pm 1.2$ & $10.9 \pm 0.6$ \\
PMNL count $(/ \mu \mathrm{l})$ & $5.9 \pm 0.2^{\dagger}$ & $3.4 \pm 0.1$ & $2.5 \pm 0.1$ \\
\hline
\end{tabular}

Data presented as mean \pm standard error of mean. $n$, number of subjects.

* Mean age was similar between groups by Kruskal-Wallis variance analysis (for each, $p>0.05$ ).

† Significantly higher than inactive patients and control subjects by Mann-Whitney U-test or Kruskal-Wallis variance analysis (for each, $p<$ 0.001 ). 
Table 3. Adenosine deaminase, thiobarbituric acid-reactive substances, superoxide dismutase, glutathione peroxidase and catalase activities in red blood cells or plasma of patients with Behçet's disease and healthy control volunteers: statistical analysis

\begin{tabular}{|c|c|c|c|}
\hline & $\begin{array}{l}\text { Active patients ( } n=17) \\
\text { (8 men, } 9 \text { women) }\end{array}$ & $\begin{array}{l}\text { Inactive patients ( } n=18) \\
\quad(8 \text { men, } 10 \text { women) }\end{array}$ & $\begin{array}{c}\text { Control subjects }(n=20) \\
\text { (9 men, } 11 \text { women) }\end{array}$ \\
\hline RBC catalase $(k / g ~ H b)$ & $115.0 \pm 5.4^{\dagger}$ & $126.5 \pm 5.3^{\dagger}$ & $160.3 \pm 4.1$ \\
\hline Plasma SOD (U/ml) & $405.7 \pm 8.4^{\dagger \S}$ & $477.0 \pm 9.0^{\dagger}$ & $636.4 \pm 9.2$ \\
\hline RBC SOD (U/g Hb) & $3392.1 \pm 65.1^{\dagger \S}$ & $4028.1 \pm 40.3^{\dagger}$ & $4849.7 \pm 49.0$ \\
\hline Plasma GSHPX $(\mathrm{U} / \mathrm{ml})$ & $70.5 \pm 2.8^{\dagger \S}$ & $75.6 \pm 0.8^{\dagger}$ & $90.6 \pm 2.9$ \\
\hline RBC GSHPx (U/g Hb) & $559.1 \pm 5.6^{\dagger \S}$ & $640.0 \pm 5.9^{\dagger}$ & $670.6 \pm 10.1$ \\
\hline Plasma AD (U/I) & $39.8 \pm 0.6$ & $32.5 \pm 0.4$ & $24.1 \pm 0.8$ \\
\hline Plasma TBARS $(\mathrm{nmol} / \mathrm{ml})$ & $4.4 \pm 0.1^{*}$ & $4.0 \pm 0.1$ & $1.6 \pm 0.1$ \\
\hline
\end{tabular}

Data presented as mean + standard error of mean. $n$, number of subjects.

* Mean age and gender ratio was similar between groups $(p>0.05)$.

†Significantly lower than control subjects by Mann-Whitney U-test or Kruskal-Wallis variance analysis (for each, $p<0.001$ ).

'Significantly higher than control subjects by Mann-Whitney U-test or Kruskal-Wallis variance analysis (for each, $p<0.001$ ).

${ }^{s}$ Significantly lower than inactive BD patients by Mann-Whitney U-test (for each, $p<0.001$ ).

'Significantly higher than inactive BD patients by Mann-Whitney U-test (for AD, $p<0.001$; for TBARS, $p=0.023$ ).

respectively, and the difference was significant $(p<$ 0.001; Table 3).

In correlation analysis, there was a significant positive correlation between plasma AD activity and TBARS levels, and significant but negative correlation between $\mathrm{AD}$ and antioxidant enzymes (Table 4). In addition, plasma TBARS levels were also negatively correlated with antioxidant enzymes. Active patients had significantly higher plasma $\mathrm{AD}$ and TBARS activities over inactive patients (for each, $p<0.001$ ). In addition, both ESR and neutrophil count were positively correlated with AD and LPO activities (for each, $p<0.001$; Table 5).

\section{Discussion}

Immune system dysregulation, T-cell and B-cell activation, immunoactive cell infiltration into the affected regions followed by accelerated neutrophil chemotaxis and phagocytosis have been implicated in $\mathrm{BD} .{ }^{6}$ Increased production of the immunoglobulins, ${ }^{6}$ pro-inflammatory cytokines, ${ }^{15} \mathrm{NO}^{\bullet 16}$ and $\mathrm{O}_{2}^{-26}$ as well as a change in lipids and lipoprotein metabolism $^{27}$ have also been demonstrated, supporting the possibility that $\mathrm{BD}$ is an immunologic disorder. Ocular involvement occurs in 50-70\% of patients and is characterised by periphlebitis, periar-

Table 4. Correlation analysis between superoxide dismutase, glutathione peroxidase, catalase, adenosine deaminase and thiobarbituric acid-reactive substances in patients with Behçet's disease

\begin{tabular}{|c|c|c|c|c|}
\hline & \multicolumn{2}{|c|}{ Behçet's patients $(n=35)$} & \multicolumn{2}{|c|}{ Control subjects $(n=20)$} \\
\hline & $r$ value & $p$ value & $r$ value & $p$ value \\
\hline $\begin{array}{l}\text { Plasma SOD-AD } \\
\text { RBC SOD-AD } \\
\text { Plasma GSHPx-AD } \\
\text { RBC GSHPx-AD } \\
\text { RBC catalase-AD } \\
\text { AD-TBARS }\end{array}$ & $\begin{array}{r}-0.855 \\
-0.884 \\
-0.375 \\
-0.893 \\
-0.498 \\
0.639\end{array}$ & $\begin{array}{r}<0.001 \\
<0.001 \\
0.026 \\
<0.001 \\
0.002 \\
<0.001\end{array}$ & $\begin{array}{r}0.364 \\
-0.141 \\
0.337 \\
0.071 \\
0.160 \\
0.215\end{array}$ & $\begin{array}{l}\text { NS } \\
\text { NS } \\
\text { NS } \\
\text { NS } \\
\text { NS } \\
\text { NS }\end{array}$ \\
\hline
\end{tabular}

$n$, Number of subjects; NS, not significant.

Table 5. Correlations between erythrocyte sedimentation rate and polymorphonuclear leukocyte count with adenosine deaminase and thiobarbituric acid-reactive substances in patients with Behçet's disease

\begin{tabular}{|c|c|c|c|c|}
\hline & \multicolumn{2}{|c|}{ Behçet's patients $(n=35)$} & \multicolumn{2}{|c|}{ Control subjects $(n=20)$} \\
\hline & $r$ value & $p$ value & $r$ value & $p$ value \\
\hline$E S R-A D$ & 0.950 & $<0.001$ & -0.164 & NS \\
\hline PMNLs-AD & 0.944 & $<0.001$ & -0.227 & NS \\
\hline ESR-TBARS & 0.567 & $<0.001$ & 0.168 & NS \\
\hline PMNLs-TBARS & 0.564 & $<0.001$ & 0.028 & NS \\
\hline
\end{tabular}

$n$, Number of subjects; NS, not significant. 
teritis, vascular occlusion and thrombosis, leading to blindness despite vigorous treatment. ${ }^{14}$ Likewise, systemic venous thrombogenesis occurs in $40 \%{ }^{28}$ of cases as a result of endothelial dysfunction ${ }^{29}$ and multifocal necrotising vasculitis with lymphocytic infiltration. ${ }^{6}$

Free radicals are derived from the metabolism of free fatty acids and arachidonic acid, and from an univalent sequential reduction of $\mathrm{O}_{2}$ with detrimental effects at both cellular and molecular levels. ${ }^{30}$ Erythrocytes are particularly sensitive to oxidative stress and are supplied with protective defence system in order to counteract excess ROS. Therefore, free radicals are scavenged by high (SOD, GSHPx, catalase) and low (ascorbic acid, $\alpha$-tocopherol) molecular weight antioxidants. ${ }^{31}$ On the other hand, if SOD and GSHPx activities decrease concomitantly, $\mathrm{O}_{2}^{--}$and $\mathrm{H}_{2} \mathrm{O}_{2}$ intermediate free radicals then accumulate and undergo the Fenton reaction. This generates the hydroxyl radical $\left(\mathrm{OH}^{\bullet}\right)$ and LPO of membrane lipids, proteins and nucleic acids, and causes the deterioration of cell transport and energy metabolism with protein and enzyme degradation, endothelial dysfunction, tissue oedema, DNA damage and eventually cellular death. ${ }^{32}$

Excessively produced free radicals by polymorphonuclear leukocytes (PMNLs) have been suggested to mediate tissue injury in $\mathrm{BD} .{ }^{6}$ Indeed, excess $\mathrm{H}_{2} \mathrm{O}_{2}-$ induced MDA production with increased macrophage activity has been demonstrated both in vivo and in vitro, suggesting increased neutrophil-derived ROS production in patients with $\mathrm{BD} .{ }^{33}$ In the present study, lower endogenous FRSEs (here represented by decreased SOD, GSHPX and catalase activities) may result in insufficient $\mathrm{O}_{2}^{--}$and $\mathrm{H}_{2} \mathrm{O}_{2}$ removal and, therefore, limited enzymatic adaptation to ROS in BD. In other words, two-fold to three-fold increased TBARS with a concomitant reduction of FRSEs support the presence of circulating pro-oxidants with cell damaging effects, making the tissues more vulnerable to toxic effects of ROS in BD. TBARS levels in the present study showed the strongest correlation with AD levels followed by ESR and PMNLs, suggesting accelerated cellular peroxidative reactions in active $\mathrm{BD}$. Indeed, the present study further demonstrated that SOD as well as GSHPX activities declined during disease activity, causing the possible deterioration of $\mathrm{H}_{2} \mathrm{O}_{2}$ elimination and excess ROS formation in exacerbation period. Therefore, the results of the current study supported our previous reports and suggested a higher need for antioxidants in such patients, especially in active disease.

$\mathrm{AD}$ is distributed throughout the human body and its physiological activity is found in T cells, where its level is five-fold to 20-fold higher than B cells. ${ }^{1}$ It is required for lymphocyte proliferation and maturation, and raised AD activity is found where cellmediated immunity is stimulated. $\mathrm{AD}$ activity is a marker of activated neutrophil functions with chemotaxis, phagocytosis and $\mathrm{O}_{2}^{\bullet-}$ production, demonstrating the possible source of ROS. We found higher $\mathrm{AD}$ activity in Behçet's patients than controls. This was to be expected, since increased cellular and humoral activities as well as the infiltration of $\mathrm{T}$ cells into the affected regions followed by a second phase of neutrophil chemotaxis are well-defined phenomena in patients with BD. ${ }^{34}$ Indeed, we found that AD activity was correlated not only with TBARS levels, but also with acute phase reactants ESR and PMNLs. Therefore, this suggested that T-cell activation and neutrophil hyperfunction with excessive free radical insult were associated with increased LPO in BD.

Since activated $\mathrm{T}$ lymphocytes cause neutrophil activation, and neutrophils are one of the main ROSgeneration systems in BD patients, increased production of AD and TBARS confirms the presence of an inter-relationship between $\mathrm{T}$ cells and neutrophils in such patients. Moreover, the present study demonstrated that decreased FRSE activities in both plasma and erythrocyte were negatively correlated with increased $\mathrm{AD}$ and $\mathrm{LPO}$ in $\mathrm{BD}$. That is, lymphocyte function increases in accordance with ROS production and LPO, suggesting a possible new activity marker for $\mathrm{AD}$ in $\mathrm{BD}$. Therefore, the current hypothesis is that infiltration of T cells into the vascular wall followed by a neutrophil chemotaxis are associated with central changes in circulating neutrophils, with activation of these cells in BD. Activated T lymphocytes may produce inflammatory cytokines through heat shock proteins in active $\mathrm{BD}$, leading to macrophage and neutrophil activations with excessive ROS generation. Indeed, this study showed that active BD patients had higher AD activity than inactive patients. Therefore, since the increase in AD activity reflects the enhanced functions of immunocompetent cells in response to inflammatory stimuli, it may be used as a simple biochemical test for rapid preliminary evaluation of the severity of disease and immune performance in BD. In other words, the clinical inference is that measurement and monitoring of $\mathrm{AD}$ may be valuable in the management of $\mathrm{BD}$ patients both in active and inactive periods.

The inflammatory process is a serious risk factor for atherosclerosis, ${ }^{35}$ one of the most common features of $\mathrm{BD} .{ }^{36}$ In addition, a higher lipoprotein level has been shown in $\mathrm{BD}$, which is correlated with acute phase reactants such as ESR, PMNLs and PMNL elastase activities, ${ }^{37}$ contributing a risk factor in the development of thrombogenic and atherosclerotic complications in such patients. Atherosclerosis, in turn, leads to the synthesis of inducible nitric oxide synthase (iNOS), the enzyme that is responsible for $\mathrm{NO}{ }^{\bullet}$ and $\mathrm{O}_{2}^{--}$generation in smooth muscle cells, macrophages and neutrophils within the vascular wall. ${ }^{38}$ Actually, $\mathrm{NO}^{\bullet}$ toxicity is now considered to be mainly mediated by its products, the peroxynitrite 


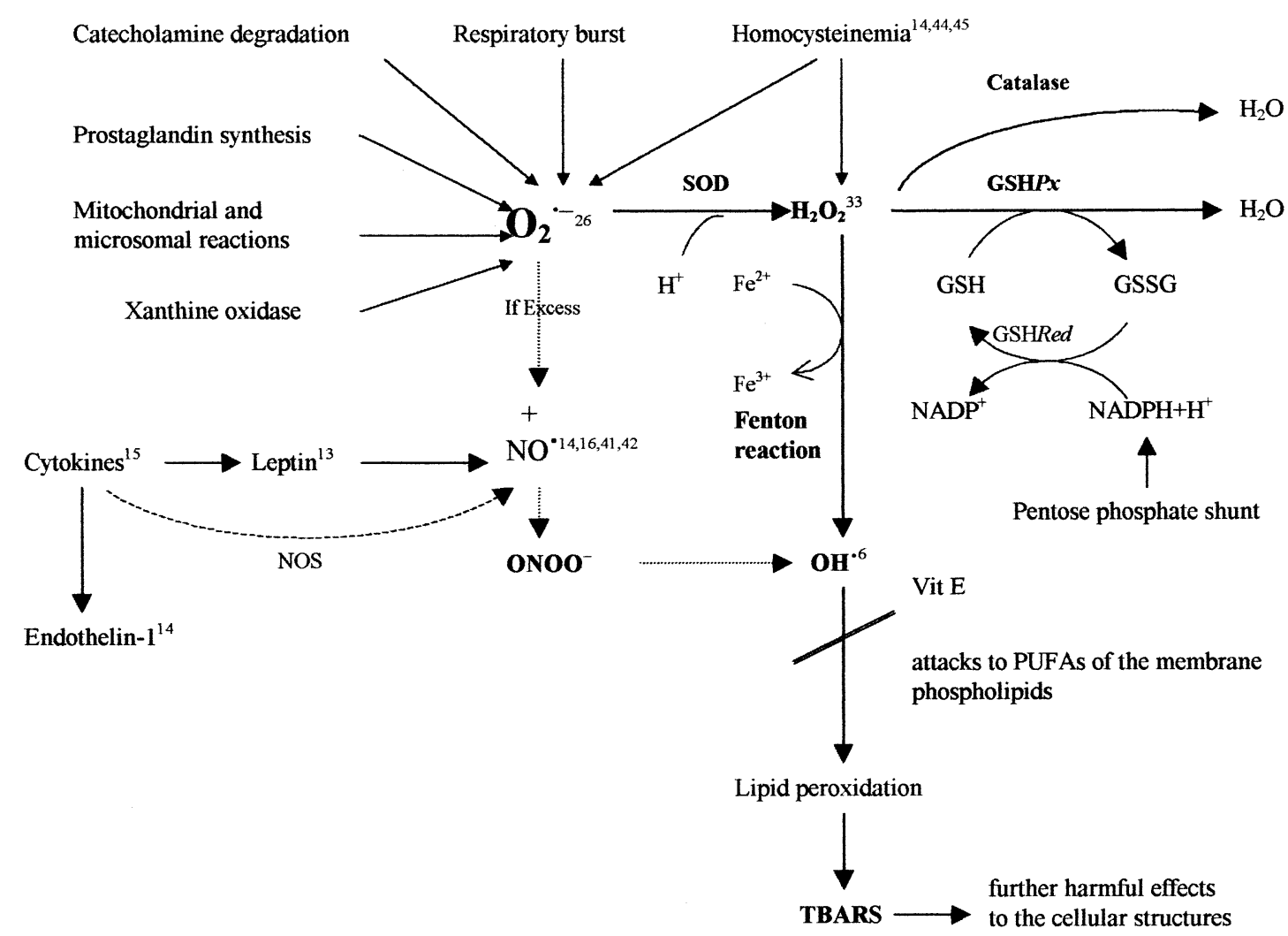

FIG. 1. Schematic representation of enzymatic ROS production, antioxidant system and lipid peroxidation in oxidative stress. Molecular oxygen can be reduced by various enzymatic reactions, and the formed superoxide anion $\left(\mathrm{O}_{2}^{-}\right)$is reduced into hydrogen peroxide $\left(\mathrm{H}_{2} \mathrm{O}_{2}\right)$ by superoxide dismutase (SOD). $\mathrm{H}_{2} \mathrm{O}_{2}$ is independently destroyed by catalase and glutathione peroxidase $(\mathrm{GSH} P x)$ in the presence of reduced glutathione $(\mathrm{GSH})$. When they are produced in excess, a Fenton reaction develops and $\mathrm{H}_{2} \mathrm{O}_{2}$ is reduced into hydroxyl radical $\left(\mathrm{OH}^{*}\right)$, the most potent ROS. Nitric oxide synthase (NOS), which produces the most abundant free radical NO ${ }^{*}$, can also contribute to oxidative stress. The short-lived NO reacts with $\mathrm{O}_{2}^{-}$, leading to peroxynitrite anion $\left(\mathrm{ONOO}^{-}\right)$production, which is a potent and powerful long-lived free oxygen radical. $\mathrm{ONOO}^{-}$further decomposes into $\mathrm{OH}^{\circ}$. The figure also shows our previous findings that could be incorporated into this figure by means of hypothetical aetiopathogenic mechanisms of BD. GSSG, oxidised glutathione; GSHRed, glutathione reductase; PUFAs, polyunsaturated fatty acids.

anion $\left(\mathrm{ONOO}^{-}\right)$and $\mathrm{OH}^{\bullet}$, mediating tissue injury and LPO. ${ }^{39,40}$

Fujita et al. ${ }^{26}$ demonstrated the generation of superoxide radical by neutrophils in $\mathrm{BD}$. Kose et $a l .{ }^{33}$ evaluated the effect of an antioxidant on lipoperoxidation induced by $\mathrm{H}_{2} \mathrm{O}_{2}$ in erythrocytes of BD patients, which is independently destroyed by catalase and GSHPX. Important in this respect is our report demonstrating increased $\mathrm{NO}^{\bullet}$ production $^{16}$ (the most abundant free radical in the body) during the course of $\mathrm{BD}$, especially in exacerbation period, which was supported by various investigations. ${ }^{14,41,42}$ In addition, Yilmaz et al. ${ }^{43}$ showed elevated aqueous humor $\mathrm{NO}^{\bullet}$ levels in BD patients afterwards. Moreover, our finding that found homocysteinemia in BD patients was supported by two independent reports. ${ }^{44,45}$ Furthermore, we have recently demonstrated that pro-inflammatory cytokines including TNF- $\alpha$, sIL-2R, IL- 6 , and chemokine IL- 8 are increased in active BD. ${ }^{15}$ Since these cytokines are known to activate neutrophil function and induce the production of $\operatorname{iNOS}^{40}$ (thus $\mathrm{NO}^{\bullet}$ ) by the upregulation of endothelial cells, the interplay between $\mathrm{AD}, \mathrm{O}_{2}^{\cdot-}$,
$\mathrm{NO}^{\bullet}$ and $\mathrm{ONOO}^{-}$in the vascular wall of $\mathrm{BD}$ is likely to cause antioxidant enzyme depletion and, therefore, oxidative LPO found in the present study. In addition, this observation was possibly due not only to endothelial cells, but also to PMNL and macrophages found in inflammation because these cells were also known to be involved in the pathogenesis of $\mathrm{BD}^{6}$ If all the previous and present findings are hypothetically incorporated in the well-known enzymatic ROS production schema, Fig. 1 can be obtained and the possible aetiopathogenic inter-relationship between the oxidative stress and antioxidant defence in such patients can clearly be observed. Based on the presented evidence, it is therefore conceivable that decreased SOD and GSHPx activities found in this study possibly pair with the increased cytokines and $\mathrm{NO}^{\bullet}$, resulting in excessive pro-oxidant production with mitochondrial respiratory enzyme inhibition in BD. Furthermore, the observation that lowered FRSEs in active BD are in line with this suggestion, indicating that the neutrophils of active patients are much more vulnerable to oxidative injury than inactive patients. 
In conclusion, this study further supported our previous studies and demonstrated not only the particular role of $\mathrm{AD}$ and $\mathrm{LPO}$ in $\mathrm{BD}$, but also emphasised lowered endogenous FRSEs in both plasma and erythrocytes in such patients. Indeed, a significant but negative correlation between antioxidant enzymes and increased AD or LPO was found, causing cellular peroxidative reactions during the disease process, especially in active disease. Amelioration of some clinical manifestations may therefore be envisaged by targeting ROS with the supplementation of dietary or pharmacological antioxidants (vitamins $\mathrm{C}$ and $\mathrm{E}$ ), which are capable of breaking the LPO chain reaction in cell membranes, thus reducing oxidative stress and improving vascular function. In addition, it would be helpful to investigate the prognostic value of changes of these prooxidative and/or antioxidative parameters during the course of therapy and to assess whether pretreatment with ROS scavengers reduces tissue damage in BD. These changes can provide insights into pathophysiology and, in a clinical situation, may be used to assess the severity of an injury. Furthermore, it appears that plasma $\mathrm{AD}$ activity can be used for the diagnosis of BD to support clinical findings and as an index for disease activity. It can also be used during the follow-up period of the patients as well as to monitor the effect of the treatment, if further studies demonstrate its sensitivity or specificity.

ACKNOWLEDGEMENTS. The authors have no financial or proprietary interest in any instrument or products used in this study.

\section{References}

1. Sullivan J, Osborne WR, Wedgewood RJ. Adenosine deaminase activity in lymphocytes. Br J Haematol 1977; 37: 157-158.

2. Bukulmez G, Akan T, Ciliu G. Serum adenosine deaminase levels in patients with psoriasis: a prospective case-control study. Eur $J$ dermatol 2000; 10: 274-276.

3. Halliwell B. Reactive oxygen species in living systems: source, biochemistry, and role in human disease. Am J Med 1991; 91: 14-22.

4. Herken H, Uz E, Ozyurt H, Sogut S, Virit O, Akyol O. Evidence that the activities of erythrocyte free radical scavenging enzymes and the products of lipid peroxidation are increased in different forms of schizophrenia. Mol Psychiatry 2001; 6: 66-73.

5. Behçet H. Uber rezidivivierende Aphthose, durch ein Virus verursachte Geschwure am Mund, am Auge und an den Genitalien. Dermatol Wochenschr 1937; 105: 1152-1157.

6. Onder M, Gurer MA. The multiple faces of Behçet's disease and its aetiological factors. J Eur Acad Dermatol Venereol 2000; 15: 126-136.

7. Evereklioglu C, Er H. Increased corneal thickness in active Behçet's disease. Eur J Ophthalmol 2002; 12: 24-29.

8. Evereklioglu C, Cokkeser, Doganay S, Er H, Kizilay A. Audio-vestibular evaluation in patients with Behçet's syndrome, J Laryngol Otol 2001. 115: $704-708$.

9. Evereklioglu C, Ozbek E, Er H, Cekmen M, Yurekli M. Urinary adrenomedullin levels are increased and correlated with plasma concentrations in patients with Behçet's syndrome. Int J Urol 2002; 9 $296-303$.

10. Gunen H, Evereklioglu C, Kosar F, Er H, Kizkin O. Thoracic involvement in Behcet's disease and its correlation with multiple parameters. Lung 2000; 178: $161-170$.

11. Turkoz Y, Evereklioglu C, Mehmet N, Cekmen M, Er H. Plasma malondialdehyde levels in Behçet's disease with or without ocular involvement. Adv Reprod 2000; 4: 31-36.

12. Evereklioglu C, Yurekli M, Er H, et al. Increased plasma adrenomedullin levels in patients with Behçet's disease. Dermatology 2000; 201: 312 315.
13. Evereklioglu C, Inaloz HS, Kirtak N, et al. Serum leptin concentration is increased in patients with Behcet's syndrome and is correlated with disease activity. Br J Dermatol 2002; 147: 331-336.

14. Er H, Evereklioglu C, Cumurcu T, et al. Serum homocysteine level is increased and correlated with endothelin-1 and nitric oxide in Behçet's disease. Br J Ophthalmol 2002; 86: 653-657.

15. Evereklioglu C, Er H, Turkoz Y, Cekmen M. Serum levels of TNF- $\alpha$, sIL$2 \mathrm{R}$, IL-6, and IL- 8 are increased and associated with elevated lipid peroxidation in patients with Behçet's disease. Mediators Inflamm 2002; 11: $87-93$.

16. Evereklioglu $\mathrm{C}$, Turkoz $\mathrm{Y}$, Er H, Inaloz HS, Ozbek E, Cekmen M. Increased nitric oxide production in patients with Behçet's disease: is it a new activity marker? J Am Acad Dermatol 2002; 46: 50-54.

17. International Study Group for Behçet's Disease. Criteria for diagnosis of Behcet's disease. Lancet 1990; 335: 1078-1080.

18. Bloch-Michel E, Nussenblatt RB. International Uveitis Study Group recommendations for the evaluation of intraocular inflammatory disease. Am J Ophthalmol 1987; 103: 234-235.

19. Aebi H. Catalase in vitro. Methods Enzymol 1984; 105: 121-126.

20. Sun Y, Oberley LW, Li Y. A simple method for clinical assay of superoxide dismutase. Clin Chem 1988; 34: 497-500.

21. Lowry OH, Rosenbrough NJ, Farr AL. Protein measurement with the Folin phenol reagent. J Biol Chem 1951; 193: 265-275.

22. Paglia DE, Valentine WN. Studies on the quantitative and qualitative characterization of erythrocyte glutathione peroxidase. J Lab Clin Med 1967; 70: $158-169$

23. Lapenna D, Ciofani G, Pierdomenico SD, Giamberardino MA, Cuccurullo F. Reactions conditions affecting the relationship between thiobarbituric acid reactivity and lipid peroxides in human plasma. Free Radic Biol Med 2001; 31: 331-335.

24. Wasowicz W, Neve J, Peretz A. Optimized steps in flourometric determination of thiobarbituric acid-reactive substances in serum: importance of extraction $\mathrm{pH}$ and influence of sample preservation and storage. Clin Chem 1993; 39: 2522-2526.

25. Giusti G. Adenosine deaminase. In: Bergmeyer HU, ed. Methods in Enzymatic Analysis. 2nd edn. New York/London: Verlag Chemie, 1974: $1092-1099$.

26. Fujita Y, Yamada M, Asai K, Mimura Y. Generation of superoxide radical by neutrophils in Behçet's disease. Nippon Ganka Gakkai Zasshi 1984; 88: $621-626$

27. Orem A, Cimsit G, Deger O, Vanizor B, Karahan SC. Autoantibodies against oxidatively modified low-density lipoprotein in patients with Behçet's disease. Dermatology 1999; 198: 243-246.

28. Lie JT. Vascular involvement in Behçet's disease: arterial and venous vessels of all sizes. J Rheumatol 1992; 19: 341-343.

29. Schmitz-Huebner U, Knop J. Evidence for an endothelial cell dysfunction in association with Behçet's disease. Thromb Res 1984; 34: $277-$ 285.

30. Crastes de Paulet A. Free radicals and aging. Ann Biol Clin 1990; 48: $323-330$.

31. Guemouri L, Artur Y, Herbeth B, Jeandel C, Siest G. Biological variability of superoxide dismutase, glutathione peroxidase, and catalase in blood. Clin Chem 1991; 37: 1932-1937.

32. Beckman KB, Ames BN. The free radical theory of aging matures. Physiol Rev 1998; 78: 547-581.

33. Kose K, Dogan P, Ascioglu M, Ascioglu O. In vitro antioxidant effect of Ginkgo biloba extract (EGb 761) on lipoperoxidation induced by hydrogen peroxide in erythrocytes of Behçet's patients. Jpn J Pharmacol 1997; 75: 253-258.

34. Niwa Y, Mizushima Y. Neutrophil-potentiating factors released from stimulated lymphocytes; special reference to the increase in neutrophilpotentiating factors from streptococcus-stimulated lymphocytes of patients with Behçet's disease. Clin Exp Immunol 1990; 79: 353-360.

35. Numano F. Vasa vasoritis, vasculitis and atherosclerosis. Int J Cardiol 2000; 31: $1-8$.

36. Iihara K, Abe J, Murakami T. Neuronal hyaline inclusions observed in an autopsy case of Behcet's disease. Acta Pathol Jpn 1992; 42: 432-438.

37. Orem A, Deger O, Cimsit G, Karahan SC, Akyol N, Yildirmis S. Plasma lipoprotein(a) and its relationship with disease activity in patients with Behçet's disease. Eur J Clin Chem Clin Biochem 1995; 33: 473-478.

38. Goldstein IM, Ostwald P, Roth S. Nitric oxide: a review of its role in retinal function and disease. Vision Res 1996; 36: 2979-2994.

39. Evereklioglu C, Er H, Doganay S, et al. Nitric oxide and lipid peroxidation are increased and associated with decreased antioxidant enzyme activities in patients with age-related macular degeneration. Doc Ophthalmol 2003; 106: 129-136.

40. Beckman JS, Beckman TW, Chen J, Marshall PA, Freeman BA. Apparent hydroxyl radical production by peroxynitrite: implications for endothelial cell injury from nitric oxide and superoxide. Proc Natl Acad Sci USA 1990; 87: $1620-1624$

41. Kiraz S, Ertenli I, Calguneri M, et al. Interactions of nitric oxide and superoxide dismutase in Behçet's disease. Clin Exp Rheumatol 2001; 19: $25-29$.

42. Salvarani C, Boiardi L, Casali B, et al. Endothelial nitric oxide synthase gene polymorphisms in Behcet's disease. J Rheumatol 2002; 29: $535-$ 540 . 
43. Yilmaz G, Sizmaz S, Yilmaz ED, Duman S, Aydin P. Aqueous humor nitric oxide levels in patients with Behcet disease. Retina 2002; 22 $330-335$

44. Lee YJ, Kang SW, Yang JI, et al. Coagulation parameters and plasma tota homocysteine levels in Behcet's disease. Thromb Res 2002; 106: 19-24.

45. Okka M, Ozturk M, Korkar MC, Bavbek N, Rasier Y, Gunduz K. Plasma homocysteine level and uveitis in Behcet's disease. Isr Med Assoc J 2002; 4: $931-934$.
Received 2 January 2003

Accepted 1 February 2003 


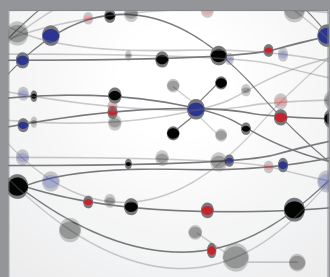

The Scientific World Journal
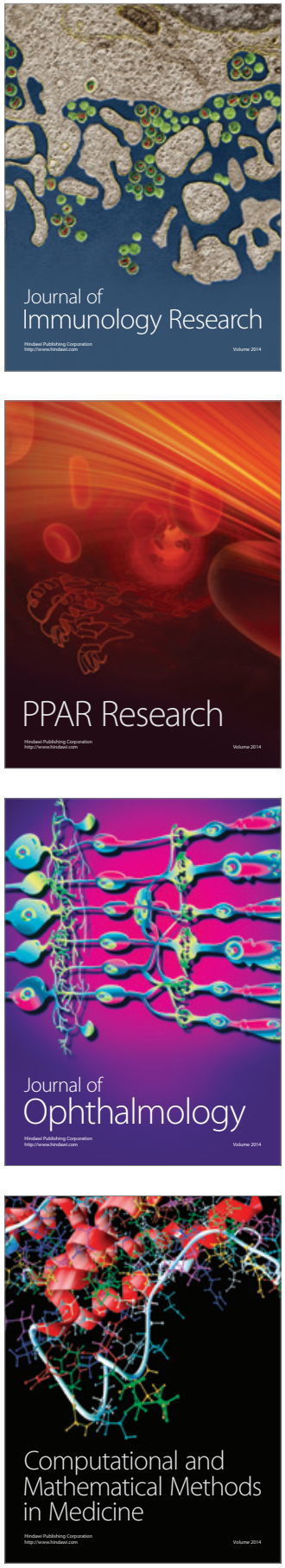

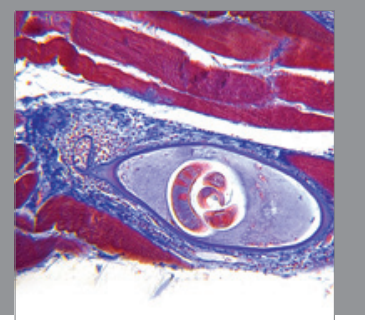

Gastroenterology

Research and Practice
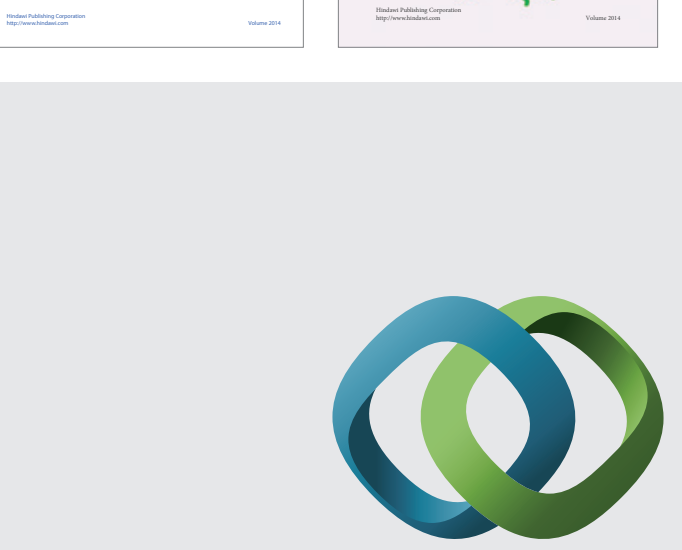

\section{Hindawi}

Submit your manuscripts at

http://www.hindawi.com
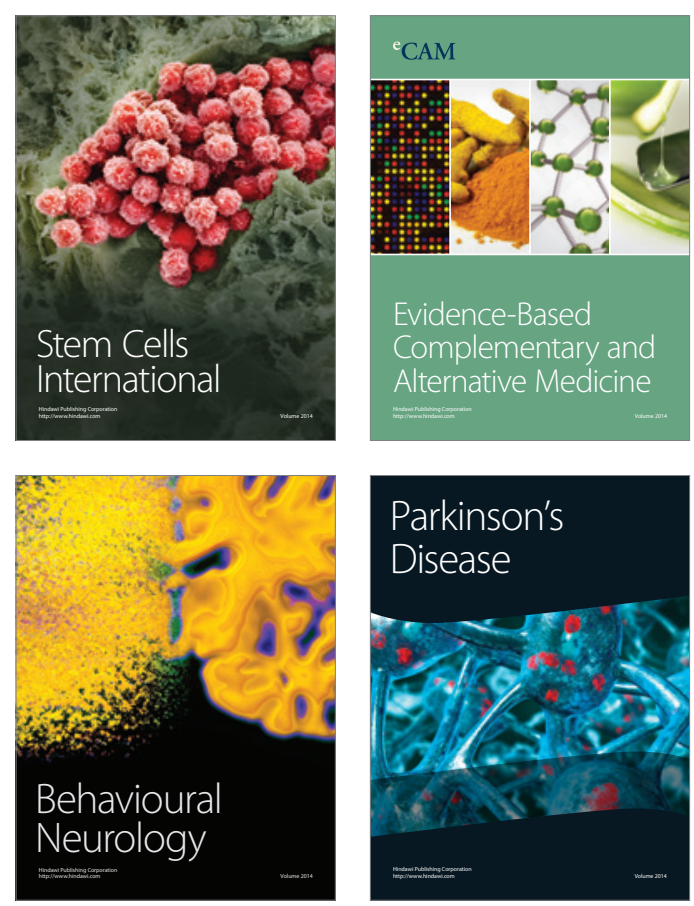

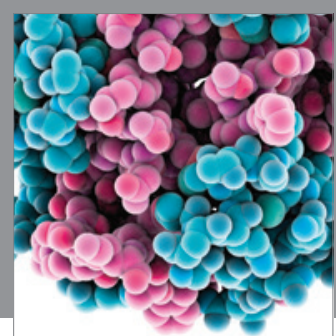

Journal of
Diabetes Research

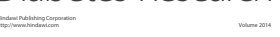

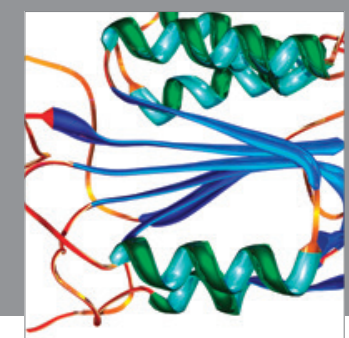

Disease Markers
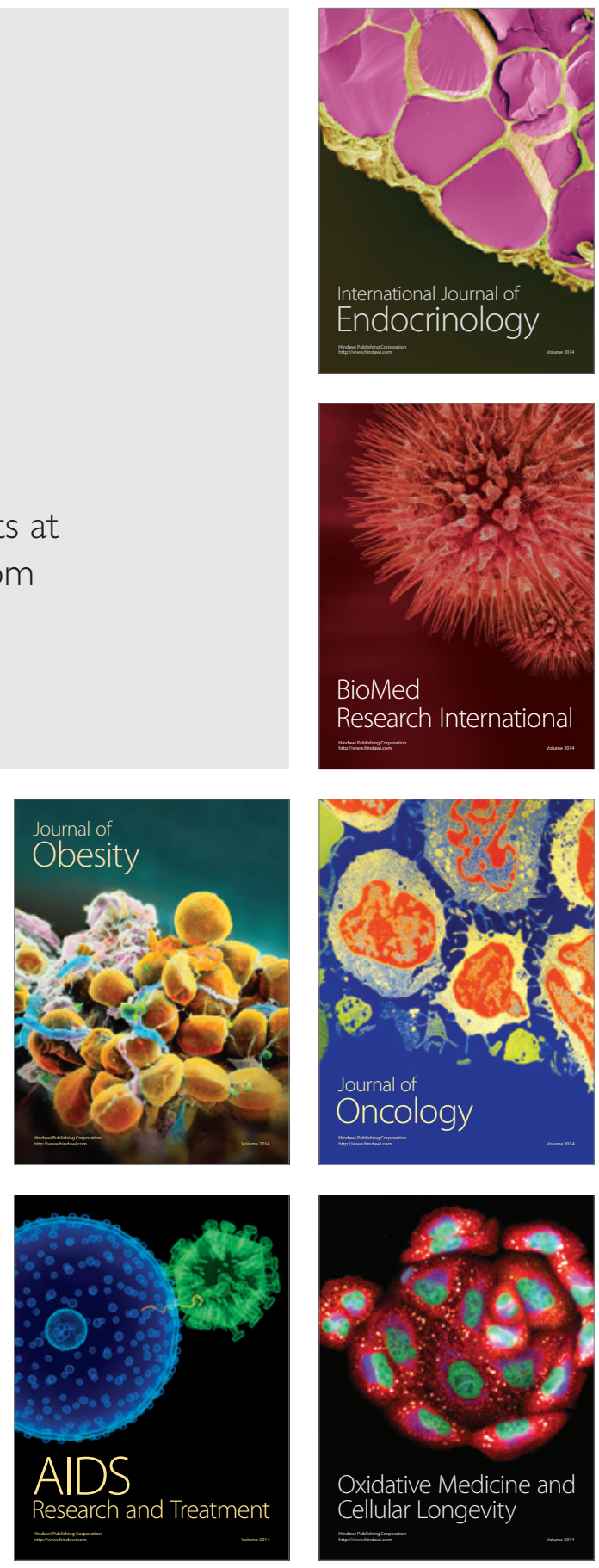